
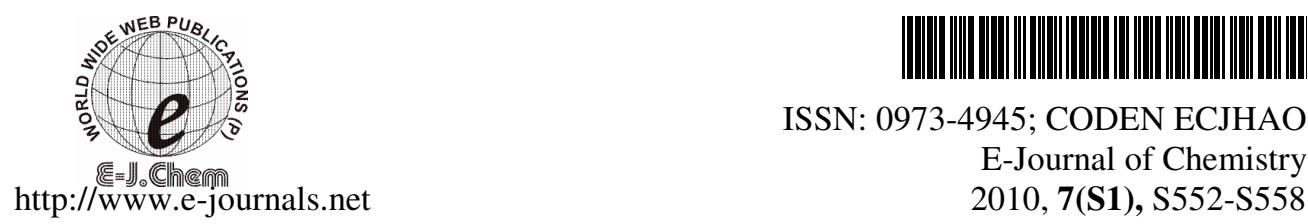

ISSN: 0973-4945; CODEN ECJHAO

E-Journal of Chemistry

2010, 7(S1), S552-S558

\title{
Pathogens and Heavy Metals Concentration in Green Leafy Vegetables
}

\author{
ABIDA BEGUM and S HARIKRISHNA \\ Department of Chemistry \\ P.E.S School of Engineering, Bangalore-560100, India \\ Department of Chemistry \\ Shirdi Sai Engineering College, Anekal, Bangalore, India \\ drabid.drabida@gmail.com
}

Received 3 March 2010; Accepted 23 May 2010

\begin{abstract}
Presence of heavy metal and bacterial pathogen in randomly collected samples of green leafy from various stations of Bengaluru city was detected. Heavy metals (cadmium, zinc, copper, iron, chromium, nickel and lead) were analyzed by tri-acid digestion method. The presence of heavy metals in general was in the order of $\mathrm{Cd}>\mathrm{Zn}>\mathrm{Cu}>\mathrm{Fe}>\mathrm{Cr}>\mathrm{Pb}$. Trace metal concentration in all green leafy vegetables of stations 1-5 were within permissible limit and it has been exceeded in station 6-10. This indicated high levels of soil contamination pose potential danger for the vegetables grown in the vicinity of Arakere lake, Bannerghatta road, Gottigere lake, Naganaikanakere, Bommasandra lake, Hulimavu lake, Kelaginakere and Amblipura lake. The total bacteria and coliforms were enumerated on TSA (Tryptone Soya Agar) and VRBA (Violet Red Bile Agar) media respectively. The total bacterial count in randomly collected samples of coriander ranged from $296 \mathrm{cfu} / \mathrm{g}$ to $8 \mathrm{cfu} / \mathrm{g}$, in palak from $16 \mathrm{cfu} / \mathrm{g}$ to $0.9 \mathrm{cfu} / \mathrm{g}$, whereas in case of cabbage was $104 \mathrm{cfu} / \mathrm{g}$ to $0.9 \mathrm{cfu} / \mathrm{g}$ which is an indication of improper pre-harvest and post harvest handling.
\end{abstract}

Keywords: Leafy vegetables, Heavy metals, Eutrophication, Pathogens.

\section{Introduction}

Human alteration of earth is substantial and growing. Between one-third and one-half of the land surface has been transformed by human action; the carbon dioxide concentration in the atmosphere has increased by nearly 30 percent since the beginning of the industrial revolution, more atmospheric nitrogen is fixed by humanity than by all natural terrestrial sources combined; more than half of all accessible surface fresh water is put to use by 
humanity and about one-quarter of the bird species on earth have been driven to extinction. By these and other standards, it is clear that we live on a human-dominated planet. Bangalore, the capital city of Karnataka, is a beautiful city complete with exquisite landscapes. It is also the city of some of the best lakes in peninsular India ${ }^{3}$. The tranquil lakes beckon peaceful walks by the lake and holidays around these lakes are always a pleasant journey for the old and new alike. Nearly 150 lakes adorn the city of Bengaluru, these lakes in Bangalore are also the major supporter of rich biodiversity increasing their overall ecological value. Some of the most beautiful lakes in Bangalore that have developed as coveted tourist spots and day trip destinations. Tanks around Bangalore and elsewhere in the state of Karnataka originally were constructed mainly for harvesting rainwater for irrigation and drinking water supply by impounding the monsoon run-off in the valleys ${ }^{1,2}$.

Rapid industrialization and urbanization in recent years have undoubtedly affected lakes and tanks in the city. Wetlands are increasingly drained and converted into housing sites, stadium and commercial complexes. Satellite images and information available with survey of India indicate that nearly 2789 lakes have dried up and there are only 330 live lakes in the medium to large range in Bengaluru metropolitan region. Urban lakes and tanks all over the country as well as in the state of Karnataka are in varying degrees of environmental degradation. The degradation is due to encroachments, eutrophication loads (from domestic and industrial effluents) and silt. The main causes for the deterioration of water quality in tanks are entering pollutants due to discharge of untreated or partially treated wastewater from municipal sewage and domestic effluents and discharge of organic, inorganic and toxic pollutants of industrial effluents. These anthropogenic activities are the main sources for the heavy metals contamination. Presence of heavy metals in environment is causing chain effects within the ecosystem. Also low concentration of essential metals (iron, zinc, copper, etc.) in living organisms causes deficiency disorders. Excessive release of heavy metals into the environment due to industrialization and urbanization has posed a great problem worldwide. Unlike organic pollutants, the majority of which are susceptible to biological degradation, heavy metal ions do not degrade into harmless end products ${ }^{1}$.

The presence of heavy metal ions is a major concern due to their toxicity to many life forms. Heavy metal contamination exists in aqueous wastes of many industries, such as metal plating, mining operations, tanneries, chloro-alkali, radiator manufacturing, smelting, alloy industries and storage batteries industries, etc. Agricultural water pollution is caused by fertilizers, insecticides, pesticides, farm animal wastes and sediments. The pathogenic organisms of these wastes transmit to the water and pose serious problems. The human sources of water pollution are due to discharge of domestic effluents and discharge of sewage. Prolonged human consumption of unsafe concentrations of heavy metals in foodstuffs may lead to the disruption of numerous biological and biochemical processes in the human body. Heavy metal accumulation gives rise to toxic concentrations in the body, while some elements act as carcinogens and others are associated with developmental abnormalities in children. Green leafy vegetables are popular around the world. They are quick growing crops that are harvested within four to six weeks. These vegetables are valuable sources of vitamins A and C, iron, calcium, folic acid, and dietary fibre. Cultivation Leafy vegetables is a profitable business for farmers, however these vegetables are highly perishable. Therefore, these vegetables are usually grown in peri-urban production areas. Proper care must be taken during irrigation pre-harvesting and post-harvesting period to avoid toxicity in vegetables before being supplied to the consumers. 


\section{Experimental}

Collection of leafy vegetable samples in triplicates were, from the agricultural production sites in the vicinity of the lakes in Bangalore. The samples collected include coriander (Coriandrum sativum) palak (Beta vulgaris L), spinach (spinacia oleracea) and Cabbage (Brassica oleracea). Standardised international protocols were followed for the preparation of material and analysis of heavy metal content. The samples were immediately oven dried at $80{ }^{\circ} \mathrm{C}$ until fully dry and were then ground to a fine powder. Samples were then digested using a tri-acid digestion process to extract the heavy metals and the resulting solutions analysed for concentrations of trace metal were determined by atomic absorption spectrophotometer. Soil from various stations was analyzed for physicochemical parameters: $\mathrm{pH}$, electrical conductivity, available sulphur, phosphorus and organic carbon and heavy metal as per the standard methods ${ }^{5,6}$.

\section{Bacterial pathogens}

Vegetables weighing $25 \mathrm{~g}$ were washed with $50 \mathrm{~mL}$ of sterile Butterfield's phosphate buffer. Washing was done by slowly rubbing the vegetable in the buffer solution. $1 \mathrm{~mL}$ of the washed solution was taken and further appropriate dilutions were made and then enumerated by plating on suitable medium ${ }^{4}$. Total bacterial count was done on Tryptone Soya agar medium. $25 \mathrm{~g}$ of vegetable samples were added to $50 \mathrm{~mL}$ Butterfield's phosphate buffer and washed in it for about 5 min further diluted the same sample in Butterfield's phosphate buffer. Appropriate dilutions were spread on Tryptone Soya agar plates in triplicates. All plates were incubated at $37{ }^{\circ} \mathrm{C}$ for $48 \mathrm{~h}$. Colonies in each plate were counted, averaged and expressed as cfu/g and converted to log. Total faecal coliforms were enumerated on violet red bile agar medium. For enumerating the total coliforms, appropriate dilutions were prepared from samples as above and were spread plated on to violet red bile agar plates in triplicates. All plates were incubated at $37{ }^{\circ} \mathrm{C}$ for $48 \mathrm{~h}$. Violet coloured colonies were counted and results were expressed as cfu/g.

\section{Results and Discussion}

Green leafy vegetables are popular around the world. They are quick growing crops that are harvested within four to six weeks. Some of the common green leafy vegetables are brassicas, lettuce, spinach, and amaranth. Tender leaves and in many cases, stems are consumed raw or cooked. These vegetables are valuable sources of vitamins A and C, iron, calcium, folic acid and dietary fibre. Cultivation of leafy vegetables is a profitable business for farmers; however, these vegetables are highly perishable. Therefore, these vegetables are usually grown in peri-urban production areas ${ }^{7}$. Proper care must be taken during irrigation pre-harvesting and post-harvesting period to avoid toxicity in vegetables before being supplied to the consumers. Presence of heavy metal and bacterial pathogen in randomly collected samples of green leafy vegetables from soils of ten lakes in Bangalore during April 2009 was detected. The vegetables [Coriander (Coriandrum sativum) palak (beta vulgaris L) and spinach (Spinacia oleracea) cabbage (Brassica oleracea)] were analysed for the heavy metals cadmium, zinc, copper, iron, chromium, nickel and lead and the total bacteria and coliforms were enumerated on TSA (tryptone soya agar) and VRBA (violet red bile agar) media respectively. The analytical data of surveyed plant samples indicated that micronutrient (via, Fe $\mathrm{Mn} \mathrm{Cu}$ and $\mathrm{Zn}$ ) content of the plant samples fell under safe range of concentration with few exceptions (classified based on standard critical limits). Name of ten stations (lakes) and their locations in and around Bengaluru ${ }^{8}$ is listed in the Table 1. Eelctrical conductivity values. (Table 2) in all the ten stations ranged from 232 to $744\left(\mu \mathrm{S} \mathrm{cm}^{-1}\right)$. Available sulphur ranged from 0.23 to $0.56(\mathrm{mg} / \mathrm{kg}), \mathrm{pH} 5.8$ to 8.6 , available phosphorus 2.13 to 5.60 $(\mathrm{mg} / \mathrm{kg}$ ) and organic carbon ranged from 0.06 to $0.15(\%)$. 
Table 1. Lakes stations and their locations in Bengaluru

\begin{tabular}{|c|c|c|}
\hline Stations & Name of the lakes & Location \\
\hline S1 & Doddakere, Hosakerehalli & $\begin{array}{l}\text { Near Hosakerehalli village adjoining } \\
\text { Banashankari III stage layout }\end{array}$ \\
\hline S2 & $\begin{array}{l}\text { Puttenahalli (Yelahanka) } \\
\text { Lake }\end{array}$ & $\begin{array}{l}\text { North of Yelahanka satellite town and along } \\
\text { Daddaballapura road }\end{array}$ \\
\hline S3 & $\begin{array}{l}\text { Begur (Aggrahara) } \\
\text { Doddakere }\end{array}$ & $\begin{array}{l}\text { towards east of Begur and towards west of } \\
\text { Hosur Road }\end{array}$ \\
\hline S4 & Varthur Lake & $\begin{array}{l}\text { towards north-west of Varthur, towards south - } \\
\text { east of Bengaluru }\end{array}$ \\
\hline S5 & $\begin{array}{l}\text { Arakere Lake, } \\
\text { Bannerghatta }\end{array}$ & $\begin{array}{l}\text { Lake is located between Hulimavu \& Arakere } \\
\text { and is abutting Banneraghatta Road }\end{array}$ \\
\hline S6 & Gottigere Lake & $\begin{array}{l}\text { Lake is located near Gottegere village which } \\
\text { exists towards the south of Bengaluru }\end{array}$ \\
\hline S7 & Naganaikanakere & $\begin{array}{l}\text { Lake is located near Beguar village, } \\
\text { Bommanahalli, Hosur Road }\end{array}$ \\
\hline S8 & Bommasandra Lake & $\begin{array}{l}\text { Lake is located near Bommsandra village, Hosur } \\
\text { Road, Attibele Hobli }\end{array}$ \\
\hline S9 & Hulimavu Lake & $\begin{array}{l}\text { Lake is located near Hulimavu village, } \\
\text { Bannerghatta Road }\end{array}$ \\
\hline S10 & $\begin{array}{l}\text { Kelaginakere Amblipura } \\
\text { Lake }\end{array}$ & $\begin{array}{l}\text { The Lake is located in the interior area south of } \\
\text { Sarjapura Road }\end{array}$ \\
\hline
\end{tabular}

Table 2. Physicochemical characterization of soil

\begin{tabular}{ccccccccccc}
\hline $\begin{array}{c}\text { Physicochemical } \\
\text { Parameter }\end{array}$ & \multirow{2}{*}{$\mathrm{S} 1$} & $\mathrm{~S} 2$ & $\mathrm{~S} 3$ & $\mathrm{~S} 4$ & $\mathrm{~S} 5$ & $\mathrm{~S} 6$ & $\mathrm{~S} 7$ & $\mathrm{~S} 8$ & $\mathrm{~S} 9$ & $\mathrm{~S} 10$ \\
\hline EC, $\mu \mathrm{S} \mathrm{cm} \mathrm{cm}^{-1}$ & 256 & 232 & 678 & 651 & 252 & 732 & 654 & 723 & 744 & 700 \\
Available S, mg/kg & 0.23 & 0.23 & 0.45 & 0.56 & 0.26 & 0.23 & 0.43 & 0.52 & 0.35 & 0.36 \\
$\mathrm{pH}$ & 7.8 & 8.6 & 5.8 & 6.1 & 7.9 & 6.6 & 6.2 & 6.5 & 6.3 & 6.5 \\
Available P, $\mathrm{mg} / \mathrm{kg}$ & 2.13 & 3.34 & 4.14 & 4.77 & 2.32 & 4.48 & 4.85 & 5.60 & 5.34 & 5.44 \\
Organic Carbon, \% & 0.08 & 0.09 & 0.12 & 0.15 & 0.07 & 0.08 & 0.08 & 0.09 & 0.06 & 0.09 \\
\hline
\end{tabular}

Tables 3-5 shows the descriptions' of heavy metals ( $\mathrm{mg} / \mathrm{kg}$ of dry wt) in random samples of palak (Beta vulgaris L) cabbage (Brassica oleracea) and spinach (Spinacia oleracea) collected from the harvested field nearby to the above mentioned lakes. All the tested heavy metals are showing their presence except for chromium and nickel (not detected) in almost all the stations. The results showed the high Fe content followed by other micronutrient might be due to high content of micronutrient in the sewage water/sewage sludge. The presence of heavy metals was in the order of $\mathrm{Cd}>\mathrm{Zn}>\mathrm{Cu}>\mathrm{Fe}>\mathrm{Cr}>\mathrm{Pb}$.

Trace metal concentration was in all green leafy vegetables in stations S1-S5 were within the permissible limit and it has exceeded in station S6-S10 with the exception for palak in station S1 the value of zinc was $94.5 \mathrm{mg} / \mathrm{kg}$ of dry wt and in station S5 the value of lead was $17.65 \mathrm{mg} / \mathrm{kg}$ of dry wt. The metal content in vegetables from agricultural fields indicates high levels of soil contamination and there is a potential danger of heavy metal accumulation particularly $\mathrm{Zn}, \mathrm{Cu}$ and $\mathrm{Cd}$ in vegetables grown in vicinity of Varthur lake, Arakere lake, Bannerghatta road, Gottigere lake, Naganaikanakere, Bommasandra lake, Hulimavu lake and Kelaginakere amblipura lake, ${ }^{9,10}$. 
Table 3. Heavy metals $(\mathrm{mg} / \mathrm{kg}$ of dry $\mathrm{wt})$ in random samples of coriander collected from fields around the lakes of Bengaluru

\begin{tabular}{cccccccc}
\hline Stations & $\mathrm{Cd}$ & $\mathrm{Zn}$ & $\mathrm{Fe}$ & $\mathrm{Cu}$ & $\mathrm{Pb}$ & $\mathrm{Cr}$ & $\mathrm{Ni}$ \\
\hline IS Standards & 3.6 & 50 & 50 & 30 & 2.5 & 20 & $1-5$ \\
S1 & 7.6 & 26 & 12.8 & 3.25 & 7.5 & $<0.05$ & $<0.04$ \\
S2 & 8.98 & 42.1 & 2.45 & 8.85 & 7.0 & $<0.04$ & $<0.04$ \\
S3 & 1.1 & 44.9 & 2.40 & 8.90 & 1.2 & $<0.04$ & $<0.04$ \\
S4 & 1.45 & 53.3 & 7.30 & 24.85 & 1.5 & $<0.05$ & $<0.04$ \\
S5 & 2.1 & 41.8 & 44.85 & 11.40 & 10.6 & $<0.05$ & $<0.04$ \\
S6 & 15.3 & 49.0 & 62.4 & 52.40 & 14.5 & $<0.05$ & $<0.04$ \\
S7 & 14.3 & 53.2 & 54.6 & 43.50 & 15.6 & $<0.05$ & $<0.04$ \\
S8 & 14.5 & 56.3 & 53.7 & 56.54 & 14.3 & $<0.04$ & $<0.04$ \\
S9 & 19.5 & 59.8 & 49.8 & 45.32 & 15.6 & $<0.04$ & $<0.04$ \\
S10 & 19.5 & 55.4 & 45.6 & 51.50 & 3.6 & $<0.04$ & $<0.04$ \\
\hline
\end{tabular}

Table 4. Heavy metals $(\mathrm{mg} / \mathrm{kg}$ of dry wt) in random samples of palak collected from fields around the lakes of Bengaluru

\begin{tabular}{cccccccc}
\hline Samples & $\mathrm{Cd}$ & $\mathrm{Zn}$ & $\mathrm{Fe}$ & $\mathrm{Cu}$ & $\mathrm{Pb}$ & $\mathrm{Cr}$ & $\mathrm{Ni}$ \\
\hline IS Standards & 3.6 & 50 & 50 & 30 & 2.5 & 20 & $1-5$ \\
S1 & 1.0 & 94.5 & 11.65 & 11.65 & 6.85 & $<0.05$ & $<0.04$ \\
S2 & 6.64 & 24.6 & 23.35 & 27.75 & 8.1 & $<0.04$ & $<0.04$ \\
S3 & 0.0 & 0.0 & 7.75 & 8.9 & 10.15 & $<0.04$ & $<0.04$ \\
S4 & 0.55 & 47.75 & 3.8 & 39.55 & 6.2 & $<0.05$ & $<0.04$ \\
S5 & 0.6 & 33.95 & 44.85 & 10.3 & 17.65 & $<0.05$ & $<0.04$ \\
S6 & 1.2 & 34.5 & 51.4 & 45.5 & $<0.05$ & 4.2 & 1.5 \\
S7 & 1.5 & 24.6 & 54.6 & 45.32 & $<0.05$ & 4.6 & 1.1 \\
S8 & 2.2 & 33.5 & 50.7 & 51.50 & $<0.05$ & 7.5 & 1.2 \\
S9 & 2.3 & 42.55 & 42.8 & 23.6 & 12.4 & 8.2 & 1.3 \\
S10 & 2.8 & 34.5 & 45.6 & 24.7 & 14.5 & 2.2 & 1.6 \\
\hline
\end{tabular}

Table 5. Heavy metals $(\mathrm{mg} / \mathrm{kg}$ of dry $\mathrm{wt}$ ) in random samples of cabbage collected from fields around the lakes of Bengaluru

\begin{tabular}{cccccccc}
\hline Samples & $\mathrm{Cd}$ & $\mathrm{Zn}$ & $\mathrm{Fe}$ & $\mathrm{Cu}$ & $\mathrm{Pb}$ & $\mathrm{Cr}$ & $\mathrm{Ni}$ \\
\hline IS Standards & 3.6 & 50 & 50 & 30 & 2.5 & 20 & $1-5$ \\
S1 & 0.55 & 28.75 & 2.45 & 9.7 & 9.95 & $<0.05$ & $<0.04$ \\
S2 & 0.3 & 26.3 & 6.75 & 9.7 & 8.61 & $<0.04$ & $<0.04$ \\
S3 & $<0.04$ & 0.0 & 9.45 & 34.95 & 4.95 & $<0.04$ & $<0.04$ \\
S4 & $<0.04$ & 47.35 & 4.55 & 7.45 & 6.35 & $<0.05$ & $<0.04$ \\
S5 & $<0.04$ & 26.05 & 2.25 & 8.2 & 2.15 & $<0.05$ & $<0.04$ \\
S6 & 6.85 & 44.85 & 44.9 & 44.9 & 6.45 & 6.6 & 1.6 \\
S7 & 8.10 & 51.4 & 53.3 & 53.3 & $<0.04$ & 7.8 & 1.4 \\
S8 & 10.15 & 54.6 & 41.8 & 41.8 & $<0.04$ & 2.3 & 1.0 \\
S9 & 6.20 & 50.7 & 49.0 & 49.0 & $<0.04$ & 2.5 & 1.5 \\
S10 & 7.60 & 44.25 & 53.2 & 53.2 & 6.24 & 6.3 & 1.1 \\
\hline
\end{tabular}


Table 5. Heavy metals $(\mathrm{mg} / \mathrm{kg}$ of dry wt) in random samples of spinach collected from fields around the lakes of Bengaluru

\begin{tabular}{cccccccc}
\hline Samples & $\mathrm{Cd}$ & $\mathrm{Zn}$ & $\mathrm{Fe}$ & $\mathrm{Cu}$ & $\mathrm{Pb}$ & $\mathrm{Cr}$ & $\mathrm{Ni}$ \\
\hline IS Standards & 3.6 & 50 & 50 & 30 & 2.5 & 20 & $1-5$ \\
S1 & 0.55 & 28.75 & 2.45 & 9.7 & 2.92 & 4.2 & $<0.04$ \\
S2 & 0.3 & 26.3 & 6.75 & 9.7 & 2.5 & 4.6 & $<0.04$ \\
S3 & 0.1 & 0.0 & 9.45 & 34.95 & 4.95 & 7.5 & $<0.04$ \\
S4 & 0.1 & 47.35 & 4.55 & 7.45 & 6.3 & 8.2 & $<0.04$ \\
S5 & 0.2 & 26.05 & 2.25 & 8.2 & 2.1 & 2.2 & $<0.04$ \\
S6 & 1.4 & 52.5 & 23.35 & 27.75 & 2.97 & 4.2 & $<0.05$ \\
S7 & 1.5 & 23.0 & 7.75 & 8.9 & 2.56 & $<0.05$ & $<0.04$ \\
S8 & 1.6 & 56.8 & 3.8 & 39.55 & 4.95 & $<0.04$ & $<0.04$ \\
S9 & 2.6 & 54.8 & 44.85 & 10.3 & 5.3 & $<0.04$ & $<0.05$ \\
S10 & 4.6 & 27.4 & 51.4 & 45,5 & 2.15 & $<0.05$ & $<0.05$ \\
\hline
\end{tabular}

Sewage water contains pathogenic microorganisms like bacteria, viruses, fungi, algae etc., having the potential risks to causes diseases can causes immense harm to public health. The water borne diseases are typhoid, paratyphoid fevers, dysentery and cholera, polio and infectious hepatitis. The responsible organisms occur in the faces or urine or infected people. Where raw untreated sewage water is used to irrigate crops helminthic disease caused by Ascaris and Trichuris spp. Bacterial pathogens in randomly collected samples of green leafy vegetables (coriander, palak and cabbage) were enumerated for bacterial pathogens mainly to asses level of post harvest contamination primarily of coliforms and total bacteria. Great variation in the bacterial count was observed in all the samples (Table 6). In palak the cfu/g of total bacterial count varied from 0.9 to too numerous to count (TNTC) while coliforms were observed to be present in negligible number to $16 \mathrm{cfu} / \mathrm{g}$. Coriander also showed total bacterial count in terms of $\mathrm{cfu} / \mathrm{g}$ the count was between negligible to TNTC and 296 and from negligible to TNTC and 256 for coliforms. Cabbage showed variation of cfu/g values ranging between negligible to 104 for total bacterial count and coliforms from negligible to $48 \mathrm{cfu} / \mathrm{g}$. The mean values showed the following order for coliforms and total bacterial count for the three vegetables. Total bacterial count was highest in coriander followed by cabbage and palak. The results of total bacterial count (Table 6) of the vegetables is an indication of improper pre harvest and post harvest handling. Pre-harvest conditions can come from irrigation water, improperly composted manure used as fertilizer, faecal contamination from human and domestic animals.

Table 6. Bacterial pathogens in random samples of green leafy vegetables

\begin{tabular}{|c|c|c|c|c|c|c|}
\hline \multirow{3}{*}{ S. No } & \multicolumn{2}{|c|}{ Coriander } & \multicolumn{2}{|c|}{ Palak } & \multicolumn{2}{|c|}{ Cabbage } \\
\hline & TSA & VRBA & TSA & VRBA & TSA & VRBA \\
\hline & cfu $\times 10^{5} / g$ & cfu $\times 10^{5} / \mathrm{g}$ & cfu $\times 10^{5} / g$ & cfu $\times 10^{5} / g$ & cfu $\times 10^{5} / g$ & cfu $\times 10^{5} / g$ \\
\hline 1 & 72 & 176 & 8 & - & 16 & 8 \\
\hline 2 & 296 & 192 & - & 8 & 8 & 8 \\
\hline 3 & TNTC & 256 & 16 & 16 & - & 8 \\
\hline 4 & 112 & - & - & 8 & 8 & 16 \\
\hline 5 & -- & 8 & TNTC & 8 & 8 & TNTC \\
\hline 6 & 16 & 40 & 8 & 8 & 24 & 16 \\
\hline 7 & 8 & 136 & 16 & TNTC & 8 & 8 \\
\hline 8 & 8 & - & 8 & TNTC & 16 & TNTC \\
\hline 9 & - & - & 0.9 & 0.9 & - & 0.9 \\
\hline 10 & 16 & - & 16 & - & 104 & 48 \\
\hline
\end{tabular}

Bile Agar) media, Cfu-Colony forming unit 


\section{Conclusion}

This study, indicated that long term and indiscriminate application of raw sewage effluent or letting of sewage water directly to agricultural field without prior treatment which contains heavy metals in association with suspended solids (sludge) particle may cause accumulation of toxic metals in surface and subsurface soils (with subsequent transfer to the food chain). And build up of heavy metals in soil profile may prove harmful not only to plants and animals but also to consumers of the harvested crops. The metal concentration in the green leafy vegetables harvested from the agricultural field of 5 lakes was higher than the permissible limits. Different agricultural field soils have different concentration of metals thus the crop (vegetables) grown in such soils have different concentration of metals in them.

\section{References}

1. Karnataka State Pollution Control Board, Water quality monitoring of lakes in and around Bangalore city, Bangalore, 2004, 1, 1-9.

2. Karnataka State Pollution Control Board, Water quality monitoring of lakes in and around Bangalore city, Bangalore, 2002, 1, 139.

3. Reddy M S and Char N V V, Lakes and Reservoirs:Research \& Management, 2006, 11(4), 227-237.

4. Schmidt W H and Moyer A J, J Bacteriol., 1944, 17, 199-209.

5. AOAC, In Official Methods of Analysis of the Association of Official Analytical Chemists, $5^{\text {th }}$ Ed., Helrich K (Ed.), AOAC International, Arlington, 1990, 22, 56 - 58.

6. Abida Begum, Ramaiah M, Harikrishna, Irfanulla Khan and Veena K, E-J Chem., 2009, 6(1), 47-52.

7. Abida Begum, Ramaiah M, Harikrishna, Irfanulla Khan and Veena K, E-J Chem 2009, 6(1), 13-22.

8. Abida Begum, Harikrishna S and Irfanulla Khan, Ramaiah M, Veena K and Vinutha K, Rasayan J Chem, 2008, 1(3), 596-601.

9. Abida Begum, Harikrishna S, Irfanulla Khan, Ramaiah M, Veena K and Vinutha.K, Rasayan J Chem., 2008, 1(3), 572-580.

10. Abida Begum, Harikrishna S, E-J Chem, 2008, 5(2), 377-384. 


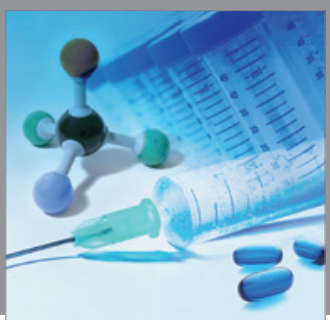

International Journal of

Medicinal Chemistry

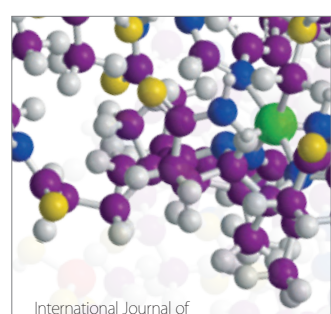

Carbohydrate Chemistry

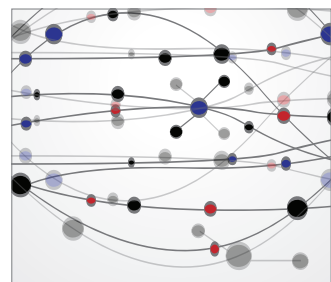

The Scientific World Journal
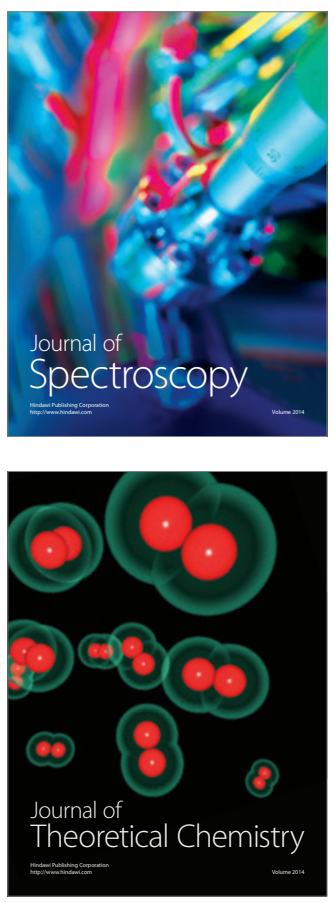
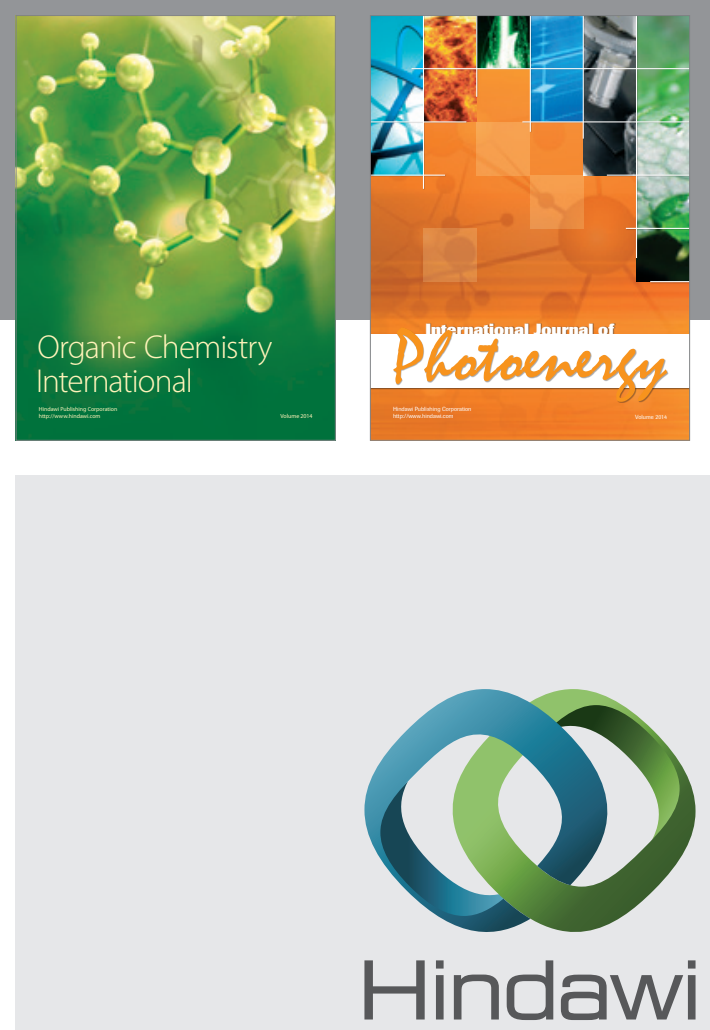

Submit your manuscripts at

http://www.hindawi.com
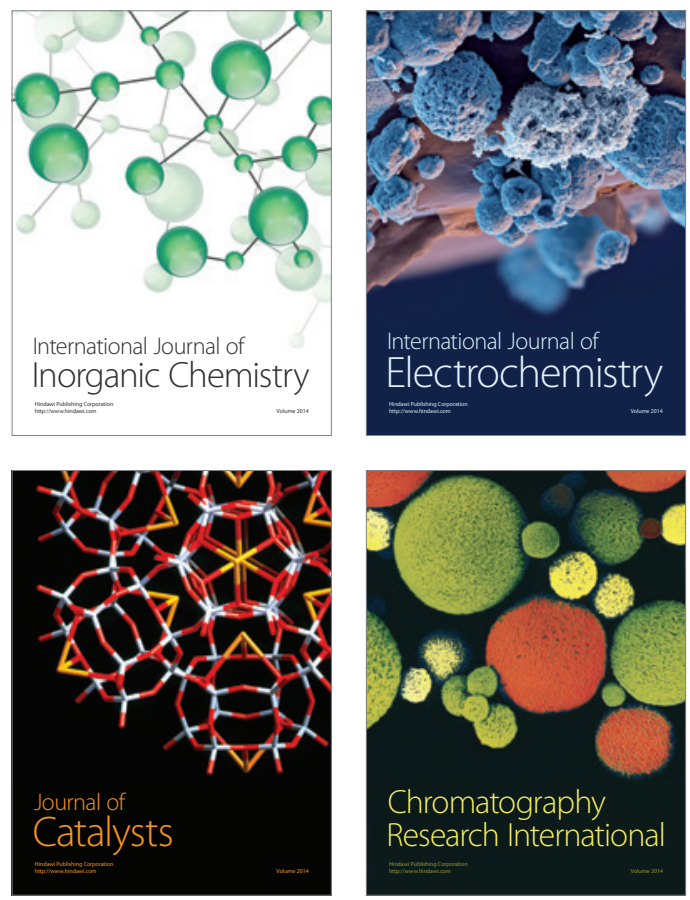
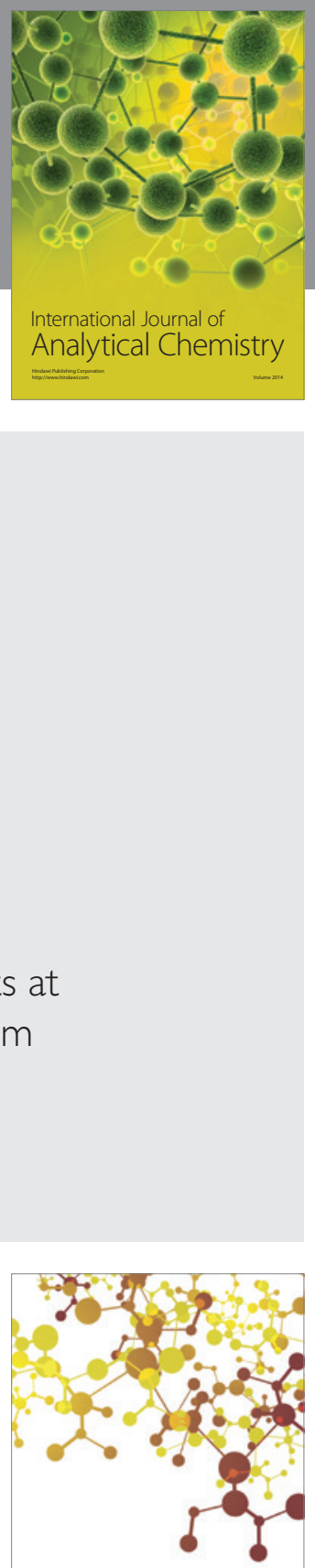

Journal of

Applied Chemistry
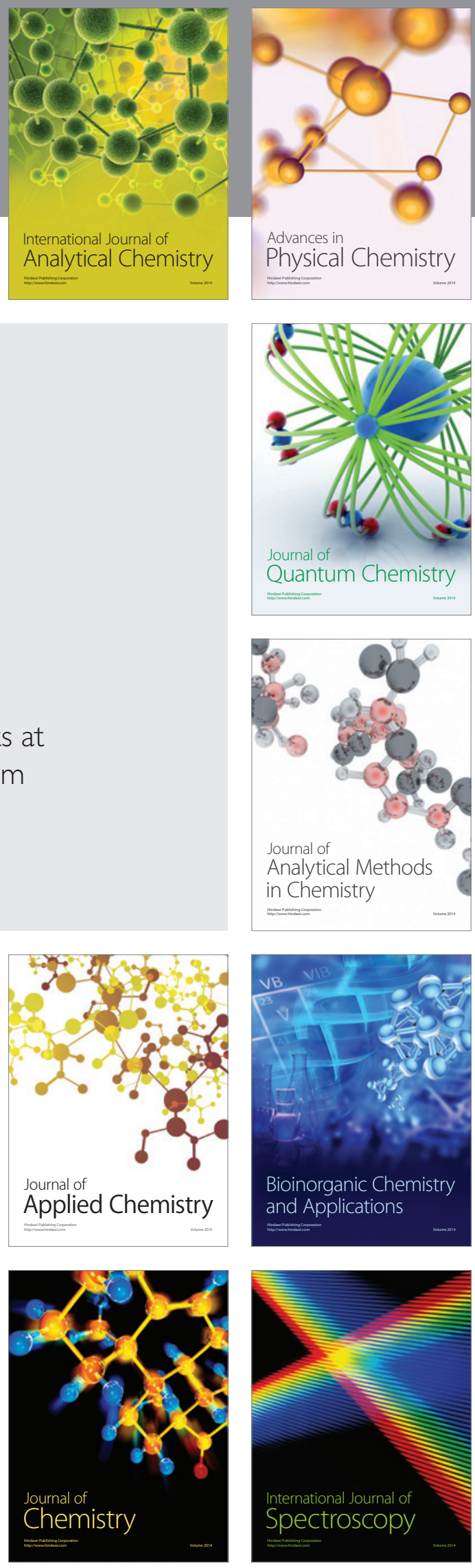